\title{
A Regional Perspective On The Underground Economy
}

\author{
Tommy C. Meadows and James A. Pihera*
}

For a variety of reasons, people wish to hold a part of their assets in the form of currency. For the past two decades the currency component of the money supply has been rising at an annual rate of about seven percent (1, p. 11). Consequently, currency has increased from 25 percent of demand deposits in 1960 to 38 percent in 1979 (1, p. 11). This amounted to average currency holdings of $\$ 500$ per capita in 1979. Obviously, the average or typical individual does not hold this much cash. The large average amount may be due to substantial cash holdings of certain atypical individuals. It has been suggested that such large currency holdings are used to facilitate illegal transactions-illegal simply because they are unreported for tax purposes or, perhaps, illegal for other reasons as well. Such unreported and/or illegal economic activity has been referred to as the underground economy (8).

Gutmann, perhaps the foremost authority on the American underground economy, pioneered the currency-based approach to estimating unreported economic activity. He estimated that such activity amounted to about ten percent of 1976 GNP (1, p. 13). This ground breaking 1977 study was simple and straight-forward. Observing that currency in circulation has been growing more rapidly than demand deposits in recent years, and because currency is the most suitable form of money for transactions that go unreported and untaxed, Gutmann concluded that the growth in currency holdings is a reflection of growth in the subterranean, extra-legal economy (8, p. 26). Estimates made by Gutmann were based on a few simple relationships and assumptions. Using the five pre-World War II years as a base, he found that the ratio of currency to demand deposits averaged .217 . This ratio increased to .344 by 1976 (8, p. 27). He then assumed that the ratio of currency to demand deposits necessary to support legal activities had not changed over the period 1937-41 to 1976; therefore, the .127 increase in currency holdings over the same time period represented funds devoted to the support of illegal activities. Thus estimated, such activities amounted to $\$ 176$ billion in unreported income in 1976 , or about 10 percent of the year's GNP (8, p. 27). Such an estimate is conservative according to Gutmann (1, p. 13) who argues that:

*Respectively, Associate Professor of Economics and Assistant Professor of Economics, Austin Peay State University, Clarksville, TN 37040. 
"It makes no allowance for unreported income in the pre-World War II base period, it takes for granted that the downward trend in the currency to demand deposit ratio would not have continued into the post-war period, it assumes all demand deposits are held for transactions and none for compensating banks for services rendered, and it ignores the growth in credit card usage and other currency saving devices."

Feige used a modification of the Gutmann technique and estimated that the underground economy was $\$ 704$ billion in 1978 (6, pp. 5-13).

A major criticism of the Gutmann method is made by Garcia, who developed a currency equation which she says shows that "No surplus currency has in fact gone to fuel the subterranean economy, because there is no surplus currency" (7, p. 66). This conclusion is based on the equation's high $\mathrm{R}^{2}$. Gutmann refutes this naive conclusion in a stinging rebuttal (9). While there is some question as to the exact size of the underground economy, most studies, like Gutmann's, conclude that the volume of underground economic activities is substantial. Bowsher provides a good, brief summary of the criticisms of Gutmann's techniques (1, p. 13). None of the criticisms appears to be sufficient to refute the methodology developed by Gutmann; therefore, we propose to use a variation of his methodology to examine the underground economy within a regional perspective.

A few studies have estimated the size, growth, and implications of the American underground economy from a national perspective $(6,8,11)$. With the exception of a few journalistic reports of underground economic activity in a specific local area, no effort has been made to examine the underground economy within a regional context. The present study is an initial effort at such an analysis.

It has long been recognized that there are regional differences or variations in economic activity. Even the organization of the Federal Reserve System into twelve Federal Reserve District Banks, each of which serves one large district or region, is tacit recognition of regional economic differences. With this in mind the question arises: are there also regional differences in underground economic activity? To answer this question we propose to examine the subterranean economic activity in the Southeast as compared to the nation as a whole. The Southeast as defined in this paper consists of the states of Alabama, Florida, Georgia, Louisiana, Mississippi, and Tennessee. A currency-based approach will be used to estimate the size of the underground economy of this region and to estimate employment when estimated underground economic activity is taken into account.

\section{PURPOSE}

The purpose of this research effort is to estimate how much employment and income are generated in each of the six Southeastern states and 
the United States by underground economic activity. We are concerned here with the absolute amounts (dollars of income and numbers of jobs) and relative amounts (the ratio of unreported to reported income and employment). Further, we intend to estimate the amount of unreported income in each of the six states relative to the Southeast and to the entire United States.

\section{METHODOLOGY}

Previous studies $(6,8)$ have estimated underground economic activity for the United States based on the currency-demand deposit ratio. Over the last three decades this ratio has been rising despite factors that should have caused it to fall. For example, the rise in currency in circulation has continued despite increases in the use of credit cards and travelers checks, factors which should reduce the need for currency (1, p. 11).

To establish a benchmark for the United States, Gutmann took the average currency to demand deposit ratio (C/DD) for 1937-41 and selected this average as a "normal" level. The average ratio was $.217(8$, p. 27). Following Gutmann, if $(\mathrm{C} / \mathrm{DD})_{\mathrm{US}}>.217$ then the implication is that there is "excess" currency which is being used to facilitate illegal transactions.

Adequate data for the years 1969-77 for the six Southeastern states and for the United States were obtained (2). For the six states and the United States M1A was calculated by adding currency $(\mathrm{C})$ and demand deposits (DD). Although M1A data for the United States are published by the Federal Reserve, it was computed here to be comparable to data for each state. For the United States, currency data used were those published by the Federal Reserve (5) and demand deposit data were computed from Federal Deposit Insurance Corporation data (2). Thus, C + DD for the United States as calculated here is approximately equal to the M1A published by the Federal Reserve. For the individual states, the value of demand deposits was computed in the same manner as for the United States (DD = demand deposits of individuals, partnerships, and corporations plus state and local governments minus cash items in process of collection). The value of currency for each state is not published since it is not directly measurable. Thus, currency values had to be estimated individually to arrive at a money supply figure for each state.

The estimate of currency (C) was based on member bank vault cash (VC) relative to total cash assets (CA). Total cash assets are equal to vault cash plus member bank deposits with the Federal Reserve plus interbank deposits. The last two items are used to clear checks while the first is held, presumably, to meet the demands of customers for currency. For estimation purposes Federal Reserve member banks were chosen since they have uniform reserve requirements. For each Southern state, and for the United States, the ratio of vault cash to total cash assets (VC/CA) was computed. 
If

$$
\left(\frac{\mathrm{VC}}{\mathrm{CA}}\right)_{\text {state }}>\left(\frac{\mathrm{VC}}{\mathrm{CA}}\right) \text { U.S. }
$$

then it was assumed this reflects a higher demand for currency, relative to demand deposits, in the state than in the nation. Thus, the state would have a higher ratio of currency to demand deposits than the nation as a whole. The ratio of vault cash to cash assets for the nation moved closely with the currency-demand deposit ratio, as evidenced by a correlation coefficient of .87 . This type of correlation may exist for the states as well.

For each year 1969-77, the ratio of currency to demand deposits (C/DD) for the United States was computed and used to estimate a corresponding value for the individual states, thus,

$$
\left(\frac{\mathrm{C}}{\mathrm{DD}}\right)_{\text {state }}=\frac{\left(\frac{\mathrm{VC}}{\mathrm{CA}}\right)_{\text {state }}}{\left(\frac{\mathrm{VC}}{\mathrm{CA}}\right) \text { U.S. }} \cdot\left(\frac{\mathrm{C}}{\mathrm{DD}}\right) \text { U.S. }
$$

Following Gutmann, the average ratio of currency to demand deposits for the period 1937-41 was used to establish a benchmark for the United States. The benchmark value was .217. A higher value for $(\mathrm{C} / \mathrm{DD})_{\text {US }}$ in later years was assumed to reflect excess currency used to support unreported transactions. State benchmarks were estimated based on the 1941 state ratios of vault cash to cash assets relative to the 1941 United States ratio of vault cash to cash assets. Thus,

$$
\text { State Benchmark }=\frac{\left(\frac{\mathrm{VC}}{\mathrm{CA}}\right) \text { state, } 1941}{\left(\frac{\mathrm{VC}}{\mathrm{CA}}\right)_{\text {U.S., } 1941}}(.217)
$$

For Mississippi and Florida these benchmarks were based on national banks only because of the small number of state member banks in these states. The benchmarks by state are: Alabama (.2454), Florida (.2807), Georgia (.2320), Louisiana (.1890), Mississippi (.3144), and Tennessee (.2036). The legally held money supply (LMS) was then calculated for each state and the United States for each year where:

$$
\text { LMS }=\left[1+\text { benchmark }\left(\frac{\mathrm{C}}{\mathrm{DD}}\right)\right] \cdot \mathrm{DD} ;
$$


as was the total money supply (TMS) where:

$$
\mathrm{TMS}=\left[1+\operatorname{actual}\left(\frac{\mathrm{C}}{\mathrm{DD}}\right)\right] . \mathrm{DD}
$$

The difference between the total money supply and legal money supply (TMS - LMS) is assumed to be currency held for underground transactions.

For each state and for the United States the velocity of circulation for reported transactions was obtained by dividing reported personal income (RPI) (3) by the legally held money supply (LMS). Total personal income (TPI), is then equal to velocity times the total money supply (TPI $=$ TMS $\times$ velocity). Assuming the velocity of circulation is the same for reported as for underground transactions, TPI includes estimated underground transactions. Total personal income minus reported personal income (TPI - RPI) gives an estimate of the dollar volume of underground activity (see Table 1).

The total employment generated by underground activity in each state and the United States was also estimated, assuming in each case that personal income per worker is the same in both the legal and the underground economy. Total employment (TE) was found by multiplying reported employment $(\mathrm{RE})$ by the ratio TPI/RPI (TE $=\mathrm{RE} \cdot(\mathrm{TPI} / \mathrm{RPI})$ ). The employment generated by illegal activity is equal to total employment minus reported employment (TE - RE) (See Table 1).

A summary of the above computations for the six states, the Southeast (six state totals), and the United States is available upon request from the authors.

\section{RESULTS}

The estimates of income and employment presented in this paper tend to indicate that the rate of participation in the underground economy in the Southeast in general is higher than for the United States as a whole for the study period. Further, participation rates in the underground economy within the Southeast are highest in Tennessee and lowest in Florida. The figures in Table 1 indicate that the absolute size of the underground economy is largest in Tennessee and smallest in Mississippi.

For each Southern state, the Southeast, and the United States underground personal income as a percentage of reported personal income is presented in Table 2. Over the period 1969-77 underground income for the United States was 8.69 percent of reported income. For the same time period underground income in the Southeast was equal to 9.84 percent of reported income. The percentage of underground income for most Southern states is above the national percentage; the major exception is Florida, while Mississippi with 8.09 percent is only slightly below the national average of 8.69 percent. Tennessee, with 16.9 percent, is the highest in the Southeast while Florida with 4.73 percent is the lowest. 
TABLE 1

Underground Income and Employment by State,

Southeastern Region and United States 1969-77

\begin{tabular}{|c|c|c|c|c|c|c|c|c|}
\hline \multirow{2}{*}{$\begin{array}{c}\text { Year } \\
1969\end{array}$} & $\begin{array}{r}\mathrm{A} \\
\mathrm{U} \\
\text { Income }\end{array}$ & $\begin{array}{l}\text { A } \\
\text { nd } \\
\text { oyment }\end{array}$ & $\begin{array}{r}\mathrm{F} \\
\mathrm{Un} \\
\text { Income }\end{array}$ & yment & Income & $\begin{array}{l}\text { A } \\
\text { ind } \\
\text { loyment }\end{array}$ & $\begin{array}{r}\mathrm{LC} \\
\mathrm{Un} \\
\text { Income }\end{array}$ & $\begin{array}{l}\text { NA } \\
\text { und } \\
\text { oloyment }\end{array}$ \\
\hline & 741 & 87 & 198 & 19 & 514 & 58 & 1079 & 116 \\
\hline 1970 & 509 & 55 & 95 & 8 & 379 & 41 & 982 & 97 \\
\hline 1971 & 851 & 86 & 751 & 63 & 254 & 26 & 1271 & 122 \\
\hline 1972 & 1215 & 116 & 63 & 5 & 1293 & 123 & 1445 & 133 \\
\hline 1973 & 1091 & 98 & 578 & 43 & 1183 & 106 & 1516 & 129 \\
\hline 1974 & 2251 & 187 & 1656 & 113 & 4693 & 390 & 2098 & 165 \\
\hline 1975 & 2490 & 185 & 3230 & 197 & 3982 & 298 & 2980 & 215 \\
\hline 1976 & 2453 & 170 & 3972 & 224 & 4341 & 304 & 2465 & 165 \\
\hline 1977 & 3076 & 200 & 5802 & 304 & 4347 & 283 & 3789 & 227 \\
\hline \multirow[b]{2}{*}{ Year } & \multicolumn{2}{|c|}{ MISSISSIPPI } & \multicolumn{2}{|c|}{ TENNESSEE } & \multicolumn{2}{|c|}{ SOUTHEAST } & \multicolumn{2}{|c|}{ UNITED STATES } \\
\hline & \multicolumn{2}{|c|}{$\begin{array}{c}\text { Underground } \\
\text { Income \& Employment }\end{array}$} & \multicolumn{2}{|c|}{$\begin{array}{c}\text { Underground } \\
\text { Income \& Employment }\end{array}$} & \multicolumn{2}{|c|}{$\begin{array}{c}\text { Underground } \\
\text { Income \& Employment }\end{array}$} & \multicolumn{2}{|c|}{$\begin{array}{c}\text { Underground } \\
\text { Income \& Employmen }\end{array}$} \\
\hline 1969 & 354 & 46 & 1212 & 155 & 4098 & 455 & 43160 & 4307 \\
\hline 1970 & 441 & 54 & 1271 & 153 & 3677 & 380 & 49867 & 4655 \\
\hline 1971 & 394 & 46 & 1427 & 162 & 4948 & 484 & 53758 & 4774 \\
\hline 1972 & 166 & 18 & 2058 & 220 & 6240 & 577 & 56221 & 4693 \\
\hline 1973 & 413 & 41 & 2335 & 228 & 7116 & 612 & 72100 & 5556 \\
\hline 1974 & 837 & 77 & 1540 & 139 & 13075 & 1036 & 99582 & 7187 \\
\hline 1975 & 1235 & 102 & 4079 & 335 & 17996 & 1282 & 126343 & 8237 \\
\hline 1976 & 825 & 63 & 5243 & 401 & 19299 & 1280 & 155856 & 9505 \\
\hline 1977 & 1285 & 91 & 7033 & 498 & 25332 & 1534 & 185395 & 10537 \\
\hline
\end{tabular}

a: Income is in millions of current dollars and employment is in thousands of workers. Source: Estimated. 
TABLE 2

Underground Personal Income as a Percent of Reported Personal Income 1969-77, Selected Southeastern States, the Southeast and the United States ${ }^{a}$

\begin{tabular}{|c|c|c|c|c|c|c|c|c|}
\hline \multirow[b]{2}{*}{ Year } & \multicolumn{8}{|c|}{ Region } \\
\hline & AL & $\mathrm{FL}$ & GA & LA & MS & $\mathrm{TN}$ & SE & US \\
\hline 1969 & 7.91 & 0.89 & 3.58 & 10.30 & 6.63 & 10.63 & 5.55 & 5.74 \\
\hline 1970 & 5.00 & 0.37 & 2.45 & 8.70 & 7.56 & 10.35 & 4.56 & 6.17 \\
\hline 1971 & 7.81 & 2.65 & 1.53 & 10.57 & 6.33 & 10.72 & 5.67 & 6.31 \\
\hline 1972 & 10.06 & 0.19 & 6.89 & 11.08 & 2.35 & 13.75 & 6.31 & 6.01 \\
\hline 1973 & 8.00 & 1.50 & 5.59 & 10.38 & 5.15 & 13.75 & 6.30 & 6.84 \\
\hline 1974 & 14.88 & 3.83 & 20.24 & 12.75 & 9.49 & 8.24 & 10.42 & 8.68 \\
\hline 1975 & 14.86 & 6.93 & 16.06 & 16.30 & 13.04 & 20.35 & 13.24 & 10.12 \\
\hline 1976 & 13.07 & 7.79 & 15.75 & 11.92 & 7.68 & 23.34 & 12.76 & 11.34 \\
\hline 1977 & 14.83 & 10.27 & 14.32 & 16.34 & 10.69 & 28.28 & 15.11 & 12.21 \\
\hline 1969-77 & 11.51 & 4.73 & 10.92 & 12.60 & 8.09 & 16.90 & 9.84 & 8.69 \\
\hline $\begin{array}{l}\% \text { of } \\
\text { Southeastern } \\
\text { underground } \\
\text { income, 1969- } \\
77 \text {, in each } \\
\text { state }\end{array}$ & 14.4 & 16.1 & 20.6 & 17.3 & 5.8 & 25.7 & & \\
\hline
\end{tabular}

a: Figures here also measure Underground Employment as a percent of Reported Employment. Source: Estimated. 
The individual state percentages for each year 1969-77 exceed the national percentage most of the time, especially from 1974 through 1977 (Table 2). Table 2 also includes the percentage of 1969-77 Southeastern unreported income that is accounted for by each state. Tennessee accounts for the highest percentage (25.7), while Mississippi accounts for the lowest percentage (5.8).

The data presented in Table 1 also suggest that underground economic activity as measured by both income and employment has increased over the study period. The estimated value of underground income and underground employment shown in Table 1 are higher in 1977 than in 1969 for both the Southeast and the United States. Further, the rate of increase appears to be greater in the Southeast than for the United States as a whole. The magnitudes of the percentage values for the Southeast and for the United States were approximately the same in 1969 (5.55 percent and 5.74 percent, respectively, Table 2). By 1977 the differential in these percentages had increased with percentages values of 15.11 percent and 12.21 percent, respectively, for the Southeast and for the United States (Table 2). Thus, the data suggest that underground economic activity appears to be growing faster in the Southeast than in the nation as a whole and is increasing faster than reported economic activity in both the Southeast and the nation. This is especially true in the cases of Tennessee, Georgia, and Florida.

The policy implications of this analysis at the national level are interesting. At the national level, macro indicators may be giving misleading signals to policymakers. Unemployment rates may be lower (and employment higher) than reported governmental figures indicate if underground employment were taken into consideration. Price level measures (CPI, etc.) may overstate price levels if prices are lower in the underground economy as a result of non-taxation. Inflation rates, however, would probably not be very different from those reported because price changes may be approximately the same in the regular economy and in the underground economy.

The policy implications at the regional level are also considerable. Because of the impact of the underground economy, regional income and employment in the Southeast may be seriously understated and more so than for the United States as a whole. The figures for underground income and employment in Table 2 suggest the relative magnitude of such understatement. This could affect such things as revenue sharing funds and welfare payments of various kinds.

Furthermore, various state, local, and regional consumer price indices are calculated and used to compare price level/cost of living in various subnational areas. Such indices may give misleading comparisons because of the impact of the underground economy, since underground prices may be lower than prices reported and used for consumer price index computation. The existence of state differentials with respect to underground participation would likely affect such consumer price indices.

Some caveats are in order at this point. Our methodology could result in overstatement of income in the underground economy. Demand deposits 
may have increased less rapidly than they otherwise would have (and thus, the ratio of currency to demand deposits may have risen more than it would have otherwise) because of the emergence of demand deposit substitutes such as NOW accounts. While this point may have some validity for the United States, it certainly is not true for the Southeast which had no NOW accounts until 1981.

While our method may have some tendency to overstate income in the underground economy, other factors exist that may cause it to understate unreported income. For example, some unreported transactions involve the use of checks while our approach assumes only currency is used. Also, barter is an undetermined factor in the underground economy and cannot be measured by this approach.

This study, like the few other completed studies of the underground economy, indicates that the underground economy is large and growing more rapidly than the regular economy. In addition, this study indicates that this phenomenon may be more pronounced in the Southeast than in the rest of the nation. Any conclusions drawn from this study, however, must be drawn cautiously. Many assumptions were necessary to obtain these estimates due to the immeasurability of something that is unreported. We plan to pursue this subject for other regions to determine the nature and extent of regional differentials in the underground economy.

\section{REFERENCES}

1. Bowsher, Norman N. "The Demand for Currency: Is The Underground Economy Undermining Monetary Policy?" Federal Reserve Bank of St. Louis Review (January, 1980): 11-17.

2. Federal Deposit Insurance Corporation, Comptroller of the Currency, and Board of Governors of the Federal Reserve System. Assets and Liabilities: Commercial and Mutual Savings Banks. Dec. 31, 1941 issue; Dec. 31, 1969 issue - Dec. 31, 1977 issue.

3. Federal Reserve Bank of Atlanta. Historical South eastern Statistics. December, 1979.

4. Monthly Southeastern Economic Indicators. December, 1979

5. . Redefined Money Stock Measures, Liquid Assets, and Related Components. February, 1980.

6. Feige, Edgar L. "How Big is the Irregular Economy?" Challenge (November/December, 1979): 5-13.

7. Garcia, Gillian. "The Currency Ratio and the Sub- terranean Economy," Financial Analysts Journal (November/December, 1977): 64-66, 69.

8. Gutmann, Peter M. "The Subterranean Economy," Financial Analysts Journal (November/December, 1977): 26-27, 34.

9. . "Professor Gutmann Replies," Financial Analysts Journal (November/December, 1978): 67-69.

10. Haulk, Charles J. "Thoughts on the Underground Economy," Economic Review, Federal Reserve Bank of Atlanta (March/April, 1980): 23-27.

11. Internal Revenue Service. Estimates of Income Unreported on Individual Tax Returns. Publication 1104, Government Printing Office, September, 1979.

12. Laurent, Robert D. "Currency and the Subterranean Economy," Economic Perspectives, Federal Reserve Bank of Chicago, (March/April, 1969):3-6.

13. Malabre, Alfred L. Jr. "Underground Economy Grows and Grows," Wall Street Journal (October 20, 1980): 1 . 